\title{
Sustainable Management of Productive Cultural Landscapes: The Pascual Harriague Wineries in Salto as a Case Study
}

\author{
Ander de la Fuente Arana ${ }^{1}$, Urtzi Llano Castresana ${ }^{2 *}$ \\ ${ }^{1}$ Department of Architecture in San Sebastian, University of the Basque Country, UPV/ EHU 20018, Spain \\ ${ }^{2}$ Department of Engineering in Bilbao, University of the Basque Country, UPV/ EHU 48013, Spain
}

Corresponding Author Email: urtzi.llano@ehu.eus

https://doi.org/10.18280/ijsdp.150608

Received: 17 January 2020

Accepted: 2 July 2020

\section{Keywords:}

image, memory, socio-system, productive

landscapes, creative management

\begin{abstract}
This article proposes guidelines for the creative management of productive cultural landscapes. These guidelines are briefly illustrated with reference to a case study: the productive cultura landscape of wine and vineyards in the riverside city of Salto, Uruguay, during the last years of the 19th century. The proposed guidelines follow the order and approaches of the links in the Landscape Value Chain. These steps are applied to the landscape from a triple approach, as memory, image and socio-system. Thus, the identification of traces and narratives of memory, elements of image and poles of opportunity of the socio-system is proposed. Each element is valued, considering its potential for re-signification and its cost. An intervention is also proposed, based on reversibility and humility. And, at all times, a process of dissemination or accountability and socialization or social dialogue is maintained. In conclusion, the recovery of a landscape must be understood as something that implies re-signifying its memory (activating its traces with narratives), the restoration of its image (giving it continuity) and restoring its social system (reactivating the socioeconomic dynamics based on the feeling of belonging), through an adequate social participation and a required subjective, non-positivistic approach to the processes, to achieve our objective: the recovery of the character of a productive cultural landscape to encourage the entrepreneurship of its inhabitants.
\end{abstract}

\section{INTRODUCTION}

At first glance, ecology and economy seem to be conflicting fields. During the last years of the $19^{\text {th }}$ century, the extreme capitalist economy leads to ecology as a result of its own needs. Economy was then interpreted as infinite and unsustainable exploitation of the physical environment (physical geography). Human action was essentially aggressive with that physical environment [1].

Since the first third of the 20th century, this "aggression" has gradually been replaced by "interaction" between human beings and their ecosystem. This has led us to the transposition of some concepts related to ecology, the study of the territory and the place and to applied human ecology [2].

The picturesque vision of the "natural" landscape, which is worthy of protection because of its intrinsic beauty, begins to be overcome $[3,4]$. The "landscape" begins to be considered as a systemic reality of human/physical environment and biotic nature relationships. Geo-ecology [5] adopts this definition as a system in contrast to the traditional concept of geographical region.

According to the European Convention of 2000, landscape is "any part of the territory perceived by the population and whose character is the result of the action and interaction of natural and/or human factors" [6]. Natural and human factors and their interrelationship are, therefore, the essence of a new definition of landscape without adjectives. In all anthropized landscapes, an exchange of energy, structure, diversity and cycles of materials is produced, due to the interaction of the community with the physical environment [7]. And in our current reality every landscape is considered "territory" [8], which means, it has a high level of anthropization.

The natural/cultural dichotomy is also hard for certain cultures to accept. Thus, as Eric L. Edroma stated at the Great Zimbabwe Congress, "the traditional African finds difficult to [...] be pushed out of the integral equation for managing the natural properties and cultural landscapes" [9].

This, among other things, shows the complexity of the landscape concept itself and the need to approach its analysis from multiple points of view.

Why, then, do we manage and analyse our landscapes according to their names: with an ecological protectionism in the natural ones, from a historicist point of view in the cultural ones or from an economic point of view in the productive ones?

\section{PRODUCTIVE LANDSCAPES: CASE STUDY}

Massimo Quaini [10] criticized the consideration of landscape as a territory, as "a set of material working conditions (the city, the countryside, etc.)". Sabaté [11], however, introduces this human action as the basis of a landscape defined as "the trace of work on the territory".

When we speak about landscapes modelled by work, we approach the concept of productive landscapes. We could define these as an opposition to the "non-productive landscape". Quoting Ann Whiston Spirin, we thus overcome the separation between "pragmatics and poetics" [12]. 
In Sabaté's definition, the term "trace" is understood as a mark left by a past action. A finished action, evoked by its traces in the collective memory of a social group, also constitutes part of the heritage of that social group. Martín Lopo [13] considers landscapes as "potential integrators of fragmented heritage". Therefore, the object of our proposal is the integration of those landscapes that are both footprint (heritage) and work (production): productive cultural landscapes.

The landscape that we take as a case study is a representation of the legacy of the industrial, commercial and agricultural-livestock activities that contributed to the development of the city of Salto, in the Eastern Republic of Uruguay, at the verge of the $19^{\text {th }}$ century (Figure 1).

The city of Salto was the port of departure to the world for goods arriving from Rio Grande do Sul (Brazil). In the 19th century, it competed in prosperity with Montevideo. This situation changed with the enhancement of the river trade laws in parallel with the construction of the Midland railway network that, since 1884, linked the region with Montevideo.

During that period of prosperity, Salto was a commercial city with a buoyant agriculture. The single-family houses of the landowners formed wide avenues according to the modern European taste. Behind that first line of houses, fruit trees were extensively grown, especially peaches. The properties extended to the outskirts in large vineyards [14].

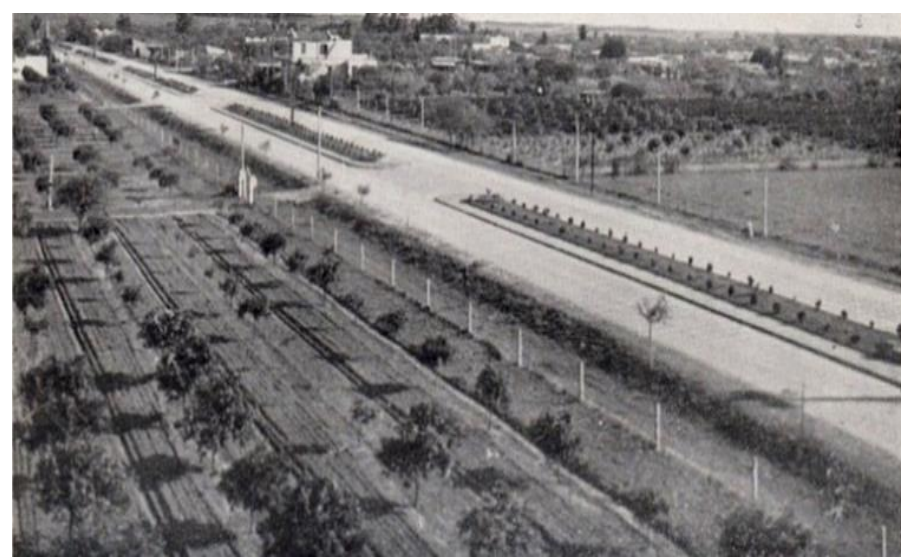

Figure 1. J. Enrique Rodó Av., the "Ciudad Lineal" of Salto, in an old photograph. Source, saltodeayer.blogspot.com

Direct communication with neighbour Concordia (Argentina) led to the entry of clones of European vines already acclimatised on the banks of Uruguay. By 1895 Salto already had more than 85 establishments and a yearly production of 2,215,693 $\mathrm{kg}$ of grapes [15], in addition to rich fruit crops.

This "area that we could call urban and that extends from our city and its suburbs to the region of San Antonio, inclusive; a true colony that tomorrow will form a great industrial town" was complemented with "the area that can be called rural and that extends throughout the rest of the Department" [16].

Pascual Harriague's winery, "La Caballada" (Figure 2), was the pioneer of this productive cultural landscape tightly linked to agriculture and the agricultural transformation industries. Even today, it is the most relevant statement and vestige of the birth of the Uruguayan viticulture from 1870 onwards. Its facilities included a salting house, a private port and, inland, vineyards, sheds and spaces for the transformation of grapes into wine [17].

\section{CREATIVE MANAGEMENT OF PRODUCTIVE CULTURAL LANDSCAPES}

The term "creative management" is based on the concept of "creative economy" defined by John Howkins in 2001 [18]. Creative management combines creativity and economics to generate added value reflected in externalities.

Our final objective is to promote the recovery of productive cultural landscapes that were ecologically sustainable and economically very profitable. Unfortunately, nowadays, they have disappeared in their traditional configuration.

We do not seek the restoration of these cultural landscapes as if they were archaeological objects. We work "for giving social, cultural and economic meaning to all heritage activities, not only those directly linked to public access and enjoyment" [19].

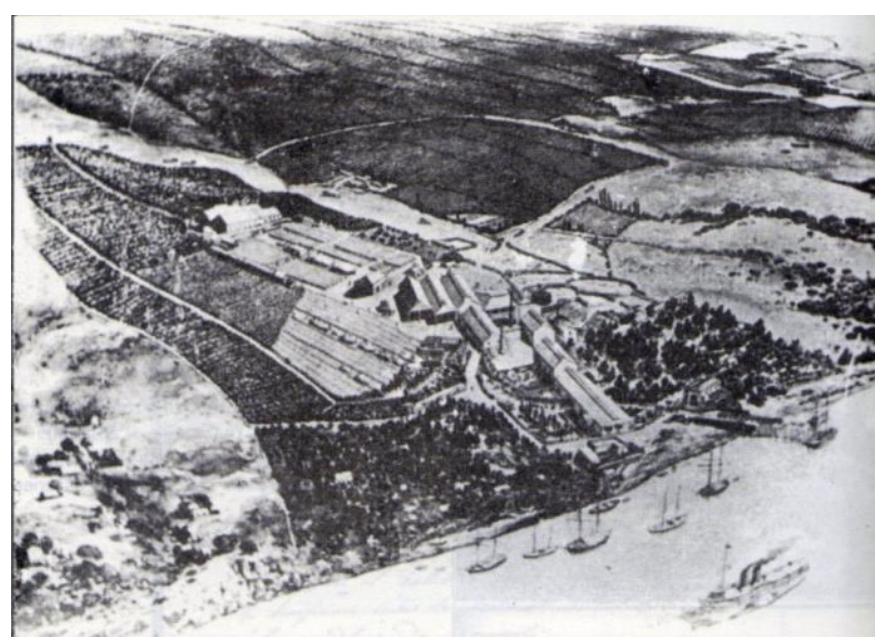

Figure 2. The extensions of "La Caballada" vineyards before 1910. Source, W.D. Castelli \& A. Grasso

In the case of Salto, the main goal is the reinforcement of the memory linked to this singular wine growing landscape that has now become heritage. This reinforcement of the memory, would offer an added value to a sustainable, handcrafted way of producing fine wines. This added value is newly gaining increasing recognition on the market, finding entrepreneurs that are ready to bet on it.

\subsection{Links for creative management}

We will establish a protocol for the creative management of productive cultural landscapes. For this purpose, we will define specific steps based on those defined in the Landscape Value Chain.

\subsubsection{Landscape value chain}

The landscape value chain is based on the cultural heritage chain defined by Felipe Criado in 1996 [20].

The links or steps in this "chain" are the following: Identification; Documentation and registration; Valuation and significance; the intervention; Dissemination and socialization and Impact and reflection (Figure 3).

\subsection{Identification of productive cultural landscapes}

The identification of landscapes means defining the elements that shape them and the subjective and objective interrelations that give them meaning as a system [21]. In other 
words, we must understand the holistic behaviour of these landscapes. This includes the parts in which they are structured, the interactions among them and why these interactions finally lead to the production the global functioning of the system [22].

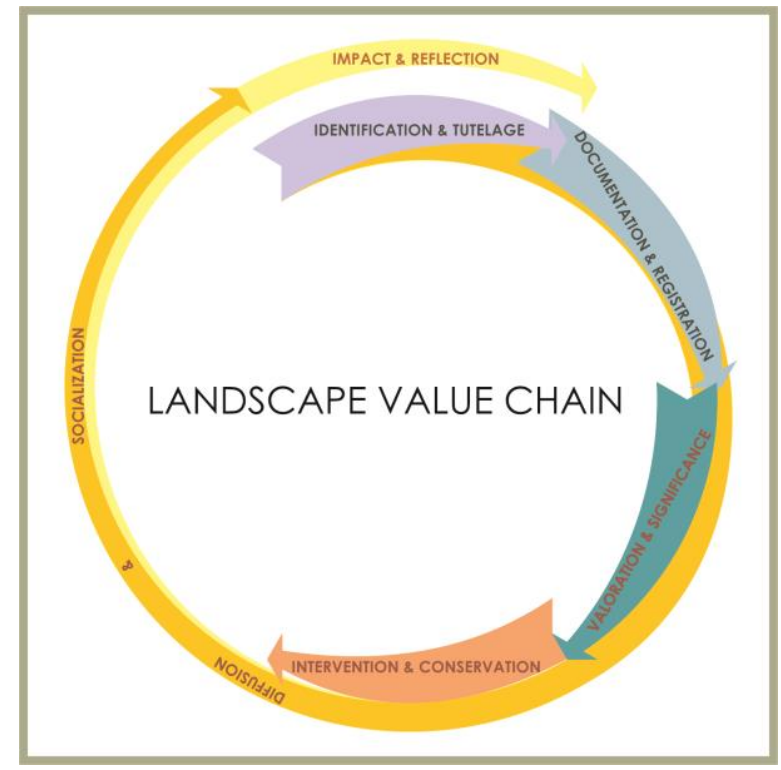

Figure 3. The landscape value chain

From this point of view, our goal should not only be to classify all the parts of a landscape. We are looking for guidelines to manage the strategically representative parts in order to characterize them. We try to find out which ones evoke a feeling of anchorage in the citizenry.

These elements or parts can be sorted out in the following:

- $\quad$ Places [23] or traces (heritage spaces) of memory [24].

- $\quad$ References (nodes, landmarks, paths, areas, edges) of the image [25].

- Spaces of collective use (direct or indirect) for the development of the socio-system, social ecosystem or socio-ecological system [26].

Then we must identify interrelations that activate the isolated elements or spaces of these landscapes. This activation "implies a process of recognition and appreciation that, far from being an automatic or innocent process, generates narratives that, by focusing on certain aspects of heritage, shape the ways in which people are related to their past, evidencing a process of social construction" [27].

The third stage of identification will establish the capacity that these relationships have to develop positive or negative dynamics depending on the next three aspects:

- The feeling of anchorage of the citizens.

- The quality of life of the inhabitants.

- Their will to preserve and enhance the environment they occupy or consider theirs.

\subsection{Documentation and registration of productive cultural landscapes}

The documentation and registration of the structuring elements of the productive cultural landscape refer, above all, to its memory aspect. These assignments comprise the study and analysis of the state of the art generated and its subsequent bibliography; the collection of testimonies associated to the project as base files and a thorough planimetric and documentary review.

In the previous link we have selected some narratives that are referred to the identified traces of memories. The most complex task of this step is the selection of those materials that match or agree with one or more of those narratives.

\subsection{Valuation and significance of productive cultural landscapes}

Three factors will be taken into account when assessing landscape elements: visibility, potential for re-signification and cost. These three factors will be analysed according to the already mentioned facets: memory, image and socio-system.

The evaluation of the memory traces of the landscape will take into account "spatial, structural, constructive, functional and even significant qualities, in relation to its condition as a constructed material associated with historical memory. This obliges us to intervene on them (landscapes) with more complex criteria than those used for a conventional public space project" [28]. The evaluation of memory narratives involves the selection of stories for their evocative potential and for generating identity.

The assessment of the elements of the landscape image will depend on its recurrent nature in the social cartography drawn up by citizens.

The evaluation of the elements of the landscape's sociosystem requires "the systematic relationship of interpersonal phenomena with ecological processes, value systems and diverse macro-structural dialectic forces that are often vaguely conceived" [29]. For this, we will adopt the system of values and capitals of Javier Carrillo [30]. The elements of the sociosystem will be evaluated in three areas:

- $\quad$ The habitat, which is characterized by natural values.

- The inhabitants, defined by artificial values.

- Their habits, determined by their evolutionary values.

\subsection{Intervention on productive cultural landscapes}

The intervention intervention on these landscapes should be guided by humility, not by the desire of leaving a mark. "It is not a question of building new landmarks, but of achieving a refined enhancement of the evocative elements that this space already possesses" [28].

\subsection{Diffusion and socialization of the landscape}

This link includes two very different dynamics: on the one hand, dissemination where society is the recipient of the message; on the other hand, socialization, which is the transmitter of some demands that we must interpret and attend to.

We include both dynamics in the same step because they both demand processes of citizen participation or social dialogue. This link also underlies the others, since the contribution of the citizens is necessary already from the identification, and in each step we must count with the addressee of the management: the society.

The social group that feels identified with the landscape being managed should be the one who identifies which of the elements of that landscape constitute traces of its collective memory. They will also have to identify which narratives "activate", in their opinion, those traces. They will need to state, which are the references of an image that they want to 
consolidate or recover. They will choose, which aspects of their traditional and everyday way of life they consider differential in the socio-economic sphere. It will also value all the elements of the landscape in each of its facets. Finally, it will endorse each step that is designed in the management project, as the final recipient of it [31].

All this must be carried out through differentiated social dialogue processes: each one with its own differentiated methodology. For this, it is necessary to have a "strong leadership, a mature civil society and notable interinstitutional cohesion" [32].

\subsection{Impact and reflection on landscape}

The project is usually terminated when a consensual outcome is reached and the intervention is completed. However, we consider that there should be a follow-up of how the management proposals work once they are implemented. For this purpose, we will use monitoring items.

The monitoring of these items should not constitute a simple collection of economic or structural materials, but evoke the social personality and character, which changes beyond each generation expressing itself in them and through them [33].

\section{RESULT: PRELIMINARY APPLICATION TO THE CASE STUDY}

The processes described below are a result of the application of our methodology [34] to the creative management of the wine growing landscape. The metodology is in this case applied to the landscape generated due to the production of Tannat wine and its marketing, located on the banks of the Uruguay River since the late 19th century.

\subsection{Results of the identification of the productive cultural landscape}

This research work analyse a traditional, productive (wine) landscape with a differentiated character. That singularity is defined by the trace of the work tradition implanted by the Basque entrepreneurs who settled in Salto since the last years of the $19^{\text {th }}$ century. The extensive plantations of vines and fruit trees are traces that have been erased today. But the constructions that served to support their elaboration or commercialization remain almost forgotten. This work has identified as memory traces the heritage elements built by those pioneers. As we have said, today the estates and vineyards are blurred and almost forgotten. However, the Pascual Harriague Winery facilities remain.

These traces are activated by a narrative of memory. The argument of this narrative revolves around the production and sale of grape wines based on Basque traditional techniques, introduced from the Basque Country (directly linked to Basque initiatives such as "La Rioja Alavesa" cultural heritage). Aspects related to the winemaking tradition introduced by these Basque pioneers have proven to awaken, in many inhabitants of Salto, a strong sense of belonging.

Today, the Wineries are a milestone in the image of the productive cultural landscape that concerns us. The proposed management should transform these spaces into a node or place where one can enter [25].

With regard to the socio-system of our landscape, we are interested in identifying poles of opportunity where we can generate dynamics of social innovation and microentrepreneurship. As territorial assets, we can focus on its natural resources (current vineyards, river, etc), as resources to promote and take into account. We identify artificial capitals of their habits such as their high cultural value (strong Basque presence channelized by the "Saltoko Euskaldunen Taldea" team) and economic value (active contribution of local winemakers) or their governance (strong involvement of the Salto Municipality through its Culture Department). As evolutionary resources, in the inhabitants, has been identified their willingness to innovation, capability to change and the strengthening of community identity revolving to its wine heritage, etc.

\subsection{Results of the documentation and registration of the productive cultural landscape}

Only basic resources have been studied concerning the previously identified narratives. The bibliography consulted refers to that period of Salto's history. We have collaborated with the Museum of Man and Technology of the city.

Apart from these conventional sources, the experience of those who managed to collect the echoes of Harriague's foundation have also been recovered. Due to their age, they were not able to experience the wineries while in operation, but their buildings and spaces were in a better state of conservation or, at least, more complete than they are today. The testimonies of former Gramond facility employees and their families (successor company to the Wineries in that same location), or of local scholars, have been recorded in social dialogue processes. The current state of the Harriague Wineries has been drawn up by UDELAR researchers on detailed plans of floors, elevations and sections that show the current state of conservation of its buildings and plots.

\subsection{Results of the assessment and significance of the productive cultural landscape}

A community can associate memories with specific elements and spaces, heritage sites or spaces that may still persist in part and that take us back to past scenarios and that are part of the character of the place. From the perspective of the memory, the most significant built spaces of the Harriague Winery have been the vat room, the roofless shed and the floor laboratory.

The vat room has also become a reference point of the image (of the landscape) for the few visitors who have already been able to enter the facilities. However, putting it in place means adapting large intermediate spaces and at present, it is very expensive.

The roofless shed constitutes a pole of opportunity for the organization of events. However, its management is still complex due to its large surface and the lack of equipment (Figure 4).

The soil laboratory (formerly, the home of the farm guard) and its surroundings have proved to be optimal spaces for the first phase of management (Figure 5). As a memory track, it is the one that has been maintained with the least alterations since 1885 . It may constitute a reference image for the local community of the neighbour district Saladero and, by extension, for the rest of the citizens. This small built space could easily become a pole of opportunity for the socio-system. It would be enough to use it as a melting point for the social agents that promote the evolutionary values concerning the 
productive (Salto's artisan winemakers), administrative (Culture Department of the City Council), and social and cultural cohesion (local associations and social driving forces).

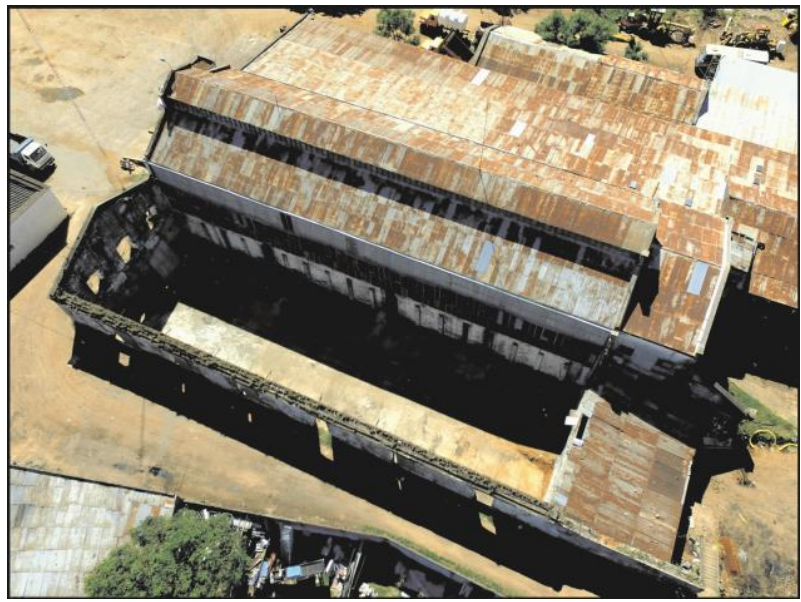

Figure 4. Harriague winery roofless shed

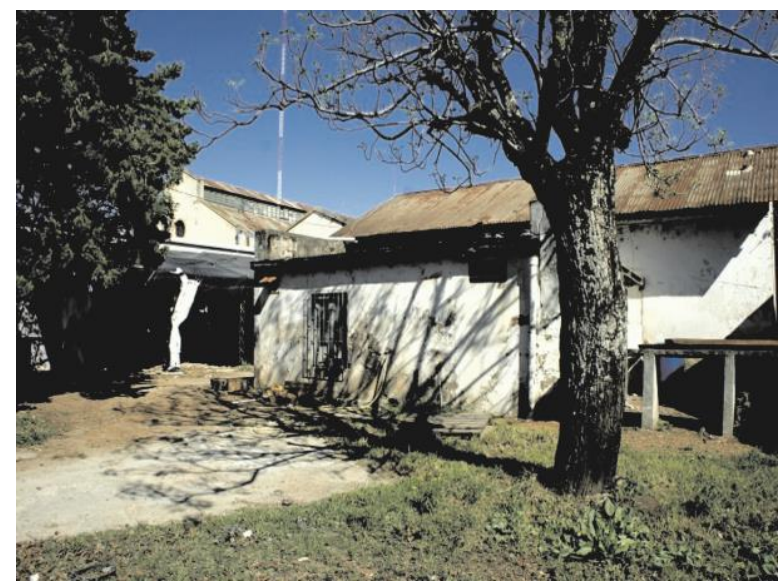

Figure 5. Winery's soil laboratory or guard house

\subsection{Results of the intervention on the productive cultural landscape}

The first fieldwork carried out on this wine-producing landscape of Salto would focus on one of its most representative and symbolic spaces: The Soil Laboratory. Through a reversible action, it is planned that this building will reconvert into a place for cultural and commercial exchange linked to traditional wine production, where, local producers will be provided a place to exhibit their new products. These products may be carried out jointly with Basque winemakers and processors who wish to actively participate in the project.

These products will be developed in joint venture with the Basque winemakers who would wish to participate in the project.

In the coming months, it is also planned to act on the following spaces (Figure 6):

(a) The exterior access esplanade. It houses the Guaviyú-Gernika space. The trees that represent the Basque people (sprout of the Tree of Gernika) and Guaraní (Guavitú) coexist in this area, embraced by a sculpture.

(b) The exterior reception/lounge counter to welcome visitors and the "taverns" or popular meals with wine tasting organized by "Saltoko Euskaldunen Taldea".
- (c) The Soil Laboratory House for the exposition of wines and wine products from Salta and the Atlantic (d) The street/museum, a space for immersion in the landscape of the Harriague Winery.

- (e) The entrance to the internal spaces. It is a direct access to the roofless shed through one of the old doors now buried.

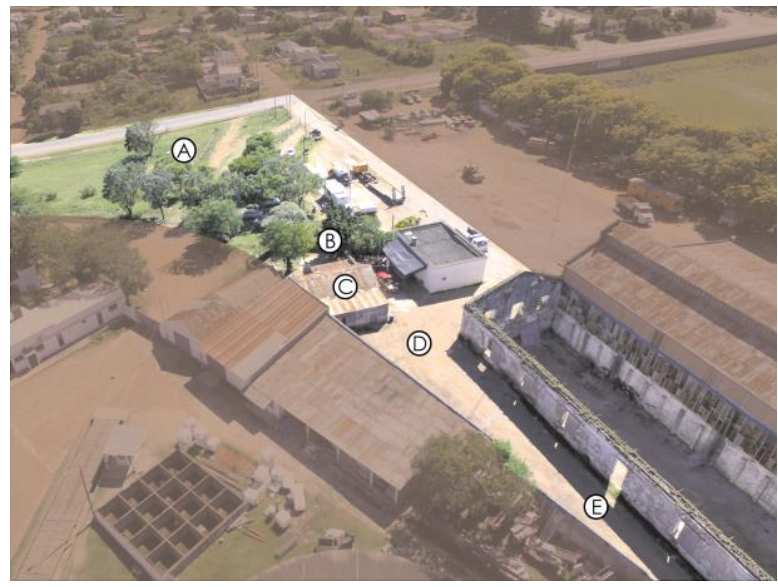

Figure 6. Diagram of the areas to be worked on

\subsection{Diffusion and socialization of the landscape}

The transmission and dissemination of the knowledge acquired about the wine production landscape and vineyards of Salto at the end of the 19th century will be the object of musealisation. The aim is to disseminate the work of Pascual Harriague as much as possible. To do so, only the essential resources will be used, designing museographic means that are as simple as impressive and ingenious (without stealing the limelight from the constructed spaces) (Figure 7).

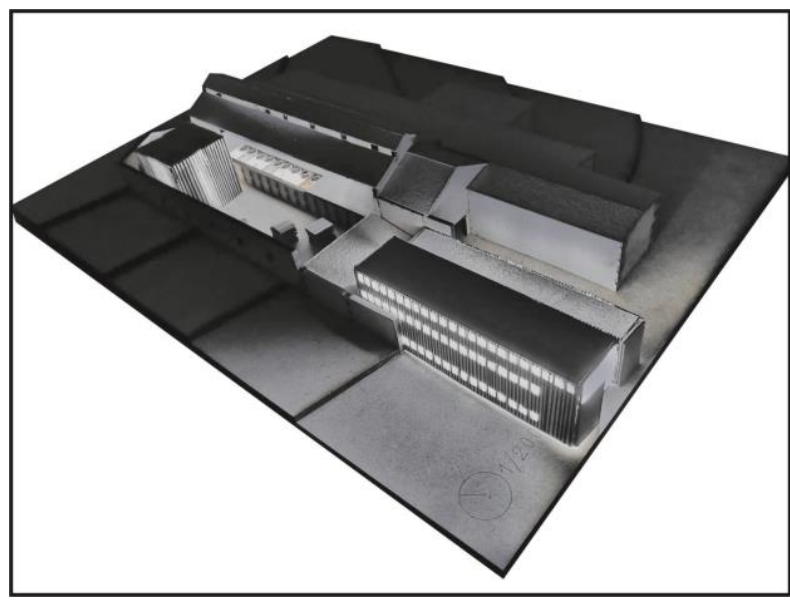

Figure 7. Proposal for a museum space of wine culture in the Harriague Winery. Source, Andoni Díez

\section{CONCLUSIONS: ENTREPRENEURSHIP}

IDENTITY

AND

The aim of our creative management is not to offer an educational product to the visitor. In contrast to this hedonistic vision, we aim to recover the old values of the good work, production and industriousness that characterised the productive cultural landscape we are dealing with. 
With this, we try to generate a feeling of identity with the pioneers who contributed to their idiosyncrasy. However, it is a subjective identity which has been transformed into economic externalities.

The economy should not evaluate the potential of a productive cultural landscape in terms of tangible capital, but by considering every element of value expressed in it.

It has been demonstrated that the feeling of being anchored in a cultural landscape and the desire to live in it predisposes people to invest and undertake.

In 2005 F.J. Carrillo points out that "to find the sustainable development of a city or region, rational and emotional; financial and relational and technological and cultural capitals are required". Let us bear in mind that "it is not the accumulation of capital - growth - but the balance of it integral development - that provides identity, health, cohesion and future viability to a society and that constitutes the true wealth of nations" (ibid.).

These productive cultural landscapes in which it manifests itself are, therefore, the scene of experimentation with evolution in innovative areas. These areas include externalities, the evaluation of the economy not only in cost-benefit terms, governance and the administrations responsible for exercising it, and the knowledge society.

\section{REFERENCES}

[1] Marsh, G.P. (2003). Man and Nature; or, Physical Geography as Modified by Human Action. Edited by David Lowenthal. With a foreword by William Cronon. Seattle: University of Washington Press.

[2] MacKaye, B. (2014). Regional Planning and Ecology. In: Ndubisi F.O. (eds) The Ecological Design and Planning Reader. Island Press, Washington, DC. https://doi.org/10.5822/978-1-61091-491-8_8

[3] Hildenbrand, A. (1993). Paisaje y política de ordenación del territorio. Análisis de la experiencia internacional comparada. Junta de Andalucía (ed.), Sevilla.

[4] Prieur, M. (1995). Le droit applicableaux paisajes en droit comparé et en droitinternational. ConseildEuropé, Estrasbourg.

[5] Troll, C. (1971). Landscape Ecology (Geoecology) and Biogeocoenology: A Terminology study. Geoforum, 8: 43-46.

[6] Council of Europe. (2000). European Landscape Convention. https://rm.coe.int/1680080621, accessed on Aug. 20, 2020.

[7] Odum, E.P., Barrett, G.W. (1971). Fundamentals of ecology. Third edition, Saunders, New York.

[8] Ingold, T. (1980). Hunters Pastoralist and Ranchers Reindeer Economies and their Transformation. Cambridge University Press, Cambridge. https://doi.org/10.1017/CBO9780511558047

[9] UNESCO. Authenticity and integrity in an African context. Galia Saouma-Forero (ed.). https://whc.unesco.org/archive/2000/whc-00-conf204inf11e.pdf, accessed on Oct. 9, 2000.

[10] Quaini, M. (1979). La construcción de la Geografía Humana. Oikos Tau, S.A., Barcelona.

[11] Sabaté, J. (2002). De la preservación del patrimonio a la ordenación del paisaje. Revista Ambiente Digital, 98: 1533.

[12] Whiston Spirn, A. (1998). The Language of Landscape.
Yale University Press.

[13] Lopo, M. (2007). Los "paisajes (culturales)" como potenciales integradores del patrimonio fragmentado; otro aporte para las clasificaciones desde una mirada territorial (nada apocalíptica). Jornadas paisajes culturales en Argentina, ICOMOS-Universidad Nacional de Rosario, Rosario.

[14] Villaverde, P. (2019). Salto de Ayer, 3 de agosto de 2015. http://www.http://saltodeayer.blogspot.com/2015/08, accessed on Jan. 11, 2019.

[15] Ecos del Progreso. (1895). Cuadro estadístico de los viñedos de Salto, levantado por Ecos del Progreso en el mes de diciembre de 1895. Revista Ecos del Progreso, Salto.

[16] Solari, B.N. (1895). Viñedos del Departamento del Salto. El Progreso, Salto.

[17] Castelli, W.D., Grasso, A. (2012). Paisaje Tannat: Cultural de viñedos y vinos en el Litoral Noroeste. Labor e Engenho, 6(1): 1-12. https://doi.og/10.20396/lobore.v6i1.16

[18] Howkins, J. (2001). The Creative Economy: How people make money from ideas. Penguin, London.

[19] COTEC. (2010). Informes sobre el sistema español de innovación. Innovación en el sector del patrimonio histórico. Fundación COTEC para la Innovación Tecnológica, Madrid. http://informecotec.es/media/B18_Inf_Inn_Sec_Patrim_ Hist.pdf.

[20] Criado, F. (1996). Hacia un modelo integrado de gestión de investigación y gestión del Patrimonio Histórico: La cadena interpretativa como propuesta. Boletín del Instituto Andaluz del Patrimonio Histórico, 16. https://doi.org/10.33349/1996.16.377

[21] Hanika, F.D.P. (1977). Ludwig von Bertalanffy: Perspectives on General System Theory - Scientific and Philosophical Studies. Journal of Society for General Systems Rsearch, 22(5): 368-371. https://doi.org/10.1002/bs.3830220508

[22] Alexander, C., Poyner, B. (1967). The Atoms of Environmental Structure. Center for Planning and Development Research, University of California.

[23] Nora, P. (1989). Les lieux de mémoire. Romantisme, 63: 103-110.

[24] Halbwachs, M. (1950). La Mémoire Collective. Presses Universitaires de France, París.

[25] Lynch, K. (1960). The Image of the City. Cambridge, MIT Press (ed.)

[26] Zipperer, W.C., Morse, W.C., Gaither, C.J. (2011). Linking social and ecological systems. Urban Ecology, 298-308. https://doi.org/10.1093/acprof:oso/9780199563562.003. 0035

[27] Torres, E., Romero, J. (2005). Gestores culturales. Entre la cultura y el patrimonio. Bulletin de l'InstitutFrançaisd'ÉtudesAndines, 34(3): 277-288. https://doi.org/10.4000/bifea.4832

[28] De la Fuente, A. (2010). Proyecto básico de puesta en valor de las Murallas Prefundacionales de VitoriaGasteiz. inédito, visado el 1 de febrero de 2010, exp. 2010 A 0030, Colegio Oficial de Arquitectos VascoNavarro, Vitoria-Gasteiz.

[29] Udy, S.H. (1968). Social structural analysis. In: Sills, D.L. (ed.), International Encyclopedia of the Social Sciences, Macmillan and Free Press. 
[30] Carrillo, F.J. (2004). Ciudades del conocimiento: el estado del arte y el espacio de posibilidades. La innovación en la sociedad del conocimiento: retos y oportunidades para l os países iberoamericanos. Medellín, Colombia.

[31] López, A., de la Fuente, A. (2020). Activación de los núcleos rurales a través del diálogo social para la gestión sostenible del paisaje en la Reserva de la Biosfera de Urdaibai (RBU). Ecosistemas, 29(1): 1924. https://doi.org/10.7818/ECOS.1924

[32] Arnold, M., Rodriguez, D. (1990). El Perspectivismo en la Teoría Sociológica. en Revista Estudios Sociales (CPU). Santiago. Chile. No64.

[33] Geddes, P. (1915). Cities in Evolution: An introduction to the Town Planning Movement and to the Study of the Cities. Ernest Benn Ltd. London.

[34] De la Fuente, A., Llano Castresana, U. (2019). Cultural landscape heritage and the construction of social identity in the production and commercialization of wine in the Ribera del Rio Uruguay. WIT Transactions on Ecology and the Environment, 238: 507-516. http://dx.doi.org/10.2495/SC190441 